\title{
Yield and Yield Components of Wheat as Influenced by Sowing Date and Humic Acid
}

\author{
Doroodian $\mathrm{M}^{1}$, Sharghi $\mathrm{Y}^{1}$, Alipour $\mathrm{A}^{1}$, Zahedi $\mathrm{H}^{1 *}$ \\ ${ }^{1}$ Department of Agronomy and Plant Breeding, Islamshahr Branch, Islamic Azad University, P.O.Box:33135- \\ 369 , Islamshahr, Iran
}

[Received: December 20, 2014; Accepted: January 29, 2015]

\begin{abstract}
In order to investigate the effect of seed sowing date and humic acid foliar application on some agronomic traits of bread wheat an experiment was conducted in Islamshahr, Iran during 2013 growing season. The experimental design was a complete randomized block design arranged in factorial with three replications. The first factor was included two sowing date (middle of November and middle of December) and the second factor was included three humic acid levels $\left(0,4\right.$ and 8 liter ha $\left.{ }^{-1}\right)$. The results indicated that late seed sowing lead to significant reduction in agronomic traits such as tiller number, spike number, seed number and seed weight. In addition, vegetative growth was affected by late seed sowing and so that shorter plants were observed. Number of days until spike emergence, number of days until pollination and number of days until physiological maturity decreased due to late seed sowing. By contrast, humic acid application increased plant growth and improved yield and yield components through extending growing period.
\end{abstract}

Keywords: Wheat, Humic acid, Seed sowing date, Yield and yield components

\section{INTRODUCTION}

Wheat (Triticum aestivum L.) is an important crop in the world. More than one third population of the world depends upon wheat as a staple food crop. It lies on the top of all cereal crops in term of calories and protein supply [1]. Variation in weather conditions is one of the most important constraints affecting yield potential [2]. Therefore, one of the requirements for obtaining high yield is the choice of the suitable sowing date [3]. It has been observed that early sowing gives high yield than late sowing due to longer growing period $[4,5]$. Too early sowing produces weak plants with poor root system as the temperature is above optimum, whereas too late planting results in poor tillering and crop grow generally slow because of low temperature [6]. According to Shafiq [7] early sowing enhanced germination per unit area, plant height, spikelets per spike, grains per spike and 1000-grain weight over late sowing. Sowing the right variety at the right time results in wheat flowering when the risk for freeze damage is the lowest and before heat stress during flowering and grain filling begins. Adequate soil moisture conditions are also important.

Application of organic fertilizers is taken into consideration all over the world, because of its importance in food safety and environmental health. Among organic fertilizers, humates are those that have great impact on plant growth and development. For instance, humic acid is one of the major components of humus. Humates have long been used as a soil conditioner, fertilizer and soil supplement. Humic acid can be used as growth regulate-hormone level improve plant growth and enhance stress tolerance [8]. Fortun et al. [9] reported that humic acid improves soil structure and change physical properties of soil, promote the chelation of many elements and make these available to plants, aid in correcting plant chlorosis, enhancement of photosynthesis density and plant root respiration has resulted in greater plant growth with humate application [10]. Increase the permeability of plant membranes due to humate application resulted in improve growth of various groups of beneficial microorganisms, accelerate cell division, increased root growth and all plant organs for a number of horticultural crops and turf grasses, as well as, the growth of some trees [11]. It has been also reported that humates increase product quality and plant tolerance to water deficit stress, salinity, heat, cold, disease and pests [12,13]. Yang et al. [14] suggested that humic materials can affect physiologic processes of plant growth directly or indirectly. Their direct effects include increasing of permeability of cellular membrane, breathing, biosynthesize nucleic acid, ionic absorption, enzymic action and pseudoenzymic action. Laboratory experiments on crop plants indicated that the use of humic substances as media amendments or foliar sprays can promote greater root and shoot growth; root branching; leaf chlorophyll content; rates of nutrient uptake, photosynthesis and respiration [10]. Mollasadeghi et al. [15] reported that the maximum chlorophyll content was related to foliar application of $200 \mathrm{mg} \mathrm{L}^{-}$ 1 humic acid at flag leaf emergence. Humic acid concentrations of 200 and $300 \mathrm{mg} \mathrm{L}^{-1}$ gave the highest biological yield and seed weight, respectively. Haghighi et al. [16] reported that humate application decreased the effect of water deficit stress on differences between plant yield under stress and no stress from 1 ton per acre to 0.1 ton. This study was aimed to investigate the effect of different humic acid concentrations and different sowing date on some agronomic characteristics of wheat. 


\section{MATERIALS AND METHODS}

In order to investigate the effects of humic acid and sowing date on some agronomic characteristics of wheat a field experiment was conducted at Islamic Azad University, Islamshahr, Iran during 2013
Number of days until spike emergence (50\% appearance), number of days until pollination and number of days until physiological maturity were counted and registered. After tiller counting, spike length (from the end of peduncle to the end of spike) and awn length (from middle spikelets) were measured. Plant height was measured from crown to the end of spike. Spike length was subtracted from

Table 1: Analysis of variance on some agronomic traits of wheat affected by seed sowing date and humic acid foliar application

\begin{tabular}{|c|c|c|c|c|c|c|c|c|c|c|c|}
\hline S.O.V & d.f & $\begin{array}{c}\text { Tiller } \\
\text { number }\end{array}$ & $\begin{array}{l}\text { Peduncle } \\
\text { length }\end{array}$ & Peduncle & $\begin{array}{l}\text { Awn } \\
\text { length }\end{array}$ & $\begin{array}{l}\text { Spike } \\
\text { length }\end{array}$ & $\begin{array}{l}\text { Stem } \\
\text { length }\end{array}$ & $\begin{array}{l}\text { Plant } \\
\text { height }\end{array}$ & $\begin{array}{c}\text { Seed } \\
\text { weight } \\
\text { in } \\
\text { spike } \\
\end{array}$ & $\begin{array}{l}\text { Spike } \\
\text { number } \\
\text { in } \mathrm{m}^{2}\end{array}$ & $\begin{array}{c}\text { Seed } \\
\text { number in } \\
\mathrm{m}^{2}\end{array}$ \\
\hline Block & 2 & ns & ns & ns & ns & ns & ns & ns & ns & $* *$ & ns \\
\hline $\begin{array}{c}\text { Sowing } \\
\text { date }\end{array}$ & 1 & $* *$ & $* *$ & $* *$ & $*$ & $* *$ & $* *$ & $* *$ & ns & ns & ns \\
\hline $\begin{array}{c}\text { Humic } \\
\text { acid }\end{array}$ & 2 & $* *$ & $*$ & ns & ns & ns & $* *$ & $* *$ & ns & $* *$ & ns \\
\hline Interaction & 2 & $\mathrm{~ns}$ & $\mathrm{~ns}$ & $\mathrm{~ns}$ & ns & ns & ns & ns & $\mathrm{ns}$ & ns & $\mathrm{ns}$ \\
\hline Error & 10 & 0.27 & 0.33 & 0.26 & 0.11 & 0.11 & 0.20 & 0.17 & 0.01 & 586.30 & 311434.12 \\
\hline C.V (\%) & & 4.95 & 1.96 & 3.25 & 0.43 & 3.85 & 0.54 & 0.44 & 11.00 & 4.39 & 10.55 \\
\hline
\end{tabular}

growing season. Thus, a factorial experiment in randomized complete block design with three replications was carried out. The first factor was included two sowing date (middle of November and middle of December) and the second factor was included three humic acid levels $(0,4$ and 8 liter ha$\left.{ }^{1}\right)$. The experimental filed was tilled with mouldboard plow and disk in fall. The experimental plots were $4 \times 2 \mathrm{~m}$, with ten sowing rows. Wheat seeds (c.v. Pishtaz) were disinfected using fungicide (Thiram, Tetra methyl thiuram disulfide) and then sown in the middle of November and December as different sowing dates. A seed rate of $150 \mathrm{~kg} \mathrm{ha}^{-1}$ was used to maintain a plant population of 4 million plants $\mathrm{ha}^{-1}$. Irrigation was applied as required during plant height to calculate stem length. The length of the last internode was considered as peduncle length. Spike number was in $0.3 \mathrm{~m}^{2}$ was recorded. In order to study yield and yield components plots were harvested and then 50 plants were selected randomly, weighted and dried at $70^{\circ} \mathrm{C}$ for $48 \mathrm{~h}$. Seed number in spike, Seed number in $\mathrm{m}^{2}$ and seed weight were calculated. Seed filling rate was calculated using following formula.

Seed filling rate $=$ seed yield/ number of days from pollination to physiological maturity

The results were submitted to statistical analysis using SAS [17]. The analysis of variance was carried out based on the level of significance in the $F$ test ( $p$ $<0.05)$. Mean values were compared using Duncan's

Table 2: Analysis of variance on some agronomic traits of wheat affected by seed sowing date and humic acid foliar application

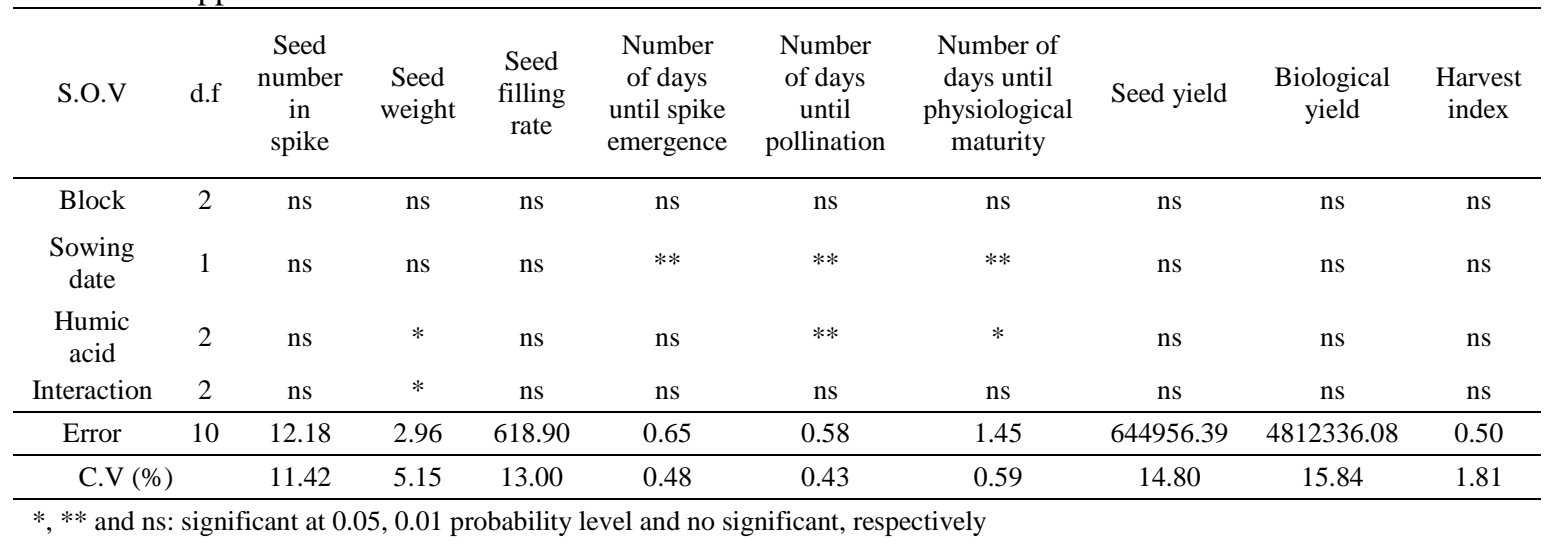

the crop growing season. The foliar treatment was carried out with humic acid solution $(0,4$ and 8 liter $\left.\mathrm{ha}^{-1}\right)$. These three solutions were sprayed on top of the leaves weekly, starting from the beginning of stem elongation until grain filling, when the flag leaf was green and showed a consistent photosynthetic activity. Distilled water was sprayed on leaves of control treatments for uniformity.
Multiple Range Test. In addition, Pearson correlation was performed.

\section{RESULTS}

The analysis of variance indicated that the effect of sowing date was significant on most of the traits such as tiller number, peduncle length, awn length, spike 
length, stem length, plant height, number of days until spike emergence, number of day until pollination and number of days until physiological maturity (Table 1 and 2). On the other hand, tiller number, peduncle length, stem length, plant height, spike number in $\mathrm{m}^{2}$, seed weight, number of days until pollination and number of days until physiological maturity were affected by humic acid application (Table 1 and 2). Interaction between sowing date and humic acid was significant just on the seed weight (Table 2). related injuries due to reduced nitrogen uptake and carbohydrate accumulation [21]. It seems that reduction in plant height due to late seed sowing is followed by a short growing period and limited vegetative growth.

Less tiller number and shorter plants as a result of late seed sowing might be due to short vegetative growth stage [22]. The effect of late seed sowing is more touchable in regions with harsh winters [23]. Late seed sowing of irrigated wheat is not recommended because of two main reasons, firstly, late seed sowing increase germination and seedling

Table 3: Main effect of sowing date on some agronomic traits of wheat

\begin{tabular}{|c|c|c|c|c|c|c|c|c|c|c|}
\hline Sowing date & $\begin{array}{c}\text { Tiller } \\
\text { number }\end{array}$ & $\begin{array}{l}\text { Peduncle } \\
\text { length } \\
(\mathrm{cm})\end{array}$ & $\begin{array}{l}\text { Peduncle } \\
\quad(\mathrm{cm})\end{array}$ & $\begin{array}{l}\text { Awn } \\
\text { length } \\
(\mathrm{mm})\end{array}$ & $\begin{array}{l}\text { Spike } \\
\text { length } \\
(\mathrm{cm})\end{array}$ & $\begin{array}{l}\text { Stem } \\
\text { length } \\
(\mathrm{cm})\end{array}$ & $\begin{array}{l}\text { Plant } \\
\text { height } \\
(\mathrm{cm})\end{array}$ & $\begin{array}{l}\text { Number of } \\
\text { days until } \\
\text { spike } \\
\text { emergence }\end{array}$ & $\begin{array}{c}\text { Number } \\
\text { of days } \\
\text { until } \\
\text { pollination }\end{array}$ & $\begin{array}{c}\text { Number of } \\
\text { days until } \\
\text { physiological } \\
\text { maturity }\end{array}$ \\
\hline November & $11.95 \mathrm{a}$ & $31.48 \mathrm{a}$ & $16.51 \mathrm{a}$ & $77.08 \mathrm{a}$ & $9.23 \mathrm{a}$ & $88.33 a$ & $97.55 \mathrm{a}$ & $172.44 \mathrm{a}$ & $178.44 \mathrm{a}$ & $206.33 a$ \\
\hline December & $9.22 \mathrm{~b}$ & $27.58 \mathrm{~b}$ & $15.10 \mathrm{~b}$ & $76.73 b$ & $8.70 \mathrm{~b}$ & $79.35 b$ & $88.04 b$ & $161.77 b$ & $170.44 b$ & $201.22 b$ \\
\hline
\end{tabular}

Values within the same column and followed by the same letter are not different at $\mathrm{P}<0.05$ by an ANOVA protected Duncan's Multiple Range Test.

Main effects of seed sowing date are given in table 3. According to the results, early seed sowing (middle of November) increased tiller number, peduncle length, awn length, spike length, stem length, plant height, number of days until spike emergence, number of days until pollination and number of days until physiological maturity compared with late sowing date (middle of December) (Table 3). In other words, late seed sowing decreased growing period. It appears that reduction in growing period cause low water and nutrient availability and limit vegetative growth in wheat plants. Reduction in plant growth and development as well as biological yield on account of late seed sowing might be due to shorter growing period before tillering stage, when it is critical to accumulate assimilates and cold tolerance factors such as anthocyanins [18]. These establishment time. Delay in seedling establishment that could be caused by cold environment, decreases tillering, stem elongation and flowering periods. Secondly, reduced tiller number as one of the most important yield components causes reduced spike number, seed number and finally seed yield [24]. Similarly, early seed showing can damage crop growth and production through a number of channels, including by encountering young seedlings with cold conditions and by sterilizing florets [25].

As mentioned before, the effect of humic acid application was significant on some agronomic traits of wheat. Main effects of humic acid application are presented in table 4 . The results indicate that humic acid increases tiller number compared with control treatment; however there was no significant

Table 4: Main effect of humic acid on some agronomic traits of wheat

\begin{tabular}{cccccccc}
\hline $\begin{array}{c}\text { Sowing } \\
\text { date }\end{array}$ & $\begin{array}{c}\text { Tiller } \\
\text { number }\end{array}$ & $\begin{array}{c}\text { Peduncle } \\
\text { length }(\mathrm{cm})\end{array}$ & $\begin{array}{c}\text { Stem } \\
\text { length } \\
(\mathrm{cm})\end{array}$ & $\begin{array}{c}\text { Plant } \\
\text { height } \\
(\mathrm{cm})\end{array}$ & $\begin{array}{c}\text { Spike } \\
\text { number in } \\
\mathrm{m}^{2}\end{array}$ & $\begin{array}{c}\text { Number of } \\
\text { days until } \\
\text { pollination }\end{array}$ & $\begin{array}{c}\text { Number of days until } \\
\text { physiological maturity }\end{array}$ \\
\hline 0 liter ha $^{-1}$ & $9.74 \mathrm{~b}$ & $29.05 \mathrm{~b}$ & $83.00 \mathrm{~b}$ & $91.83 \mathrm{~b}$ & $522.33 \mathrm{~b}$ & $173.33 \mathrm{~b}$ & $202.50 \mathrm{~b}$ \\
4 liter ha $^{-1}$ & $10.68 \mathrm{a}$ & $29.51 \mathrm{ab}$ & $83.96 \mathrm{a}$ & $93.10 \mathrm{a}$ & $551.33 \mathrm{ab}$ & $174.83 \mathrm{a}$ & $203.66 \mathrm{ab}$ \\
8 liter ha $^{-1}$ & $11.34 \mathrm{a}$ & $30.03 \mathrm{a}$ & $84.55 \mathrm{a}$ & $93.46 \mathrm{a}$ & $577.83 \mathrm{a}$ & $175.16 \mathrm{a}$ & $205.16 \mathrm{a}$ \\
\hline
\end{tabular}

Values within the same column and followed by the same letter are not different at $\mathrm{P}<0.05$ by an ANOVA protected Duncan's Multiple Range Test

results are in accordance with those of Sharief and Keshta [19] who found 20 days delay in seed sowing would decrease biological yield significantly. Similarly, Chen et al. [20] have shown that early seed sowing decreases risk of late season drought stress and improve dry matter accumulation in plants. Moreover, late seed sowing produces slim and weak plants susceptible to lodging. It has been reported that late seed sowing increases possibility of cold difference between 4 and 8 liter ha $^{-1}$ humic acid treatments (Table 4). Similar results were found in case of peduncle length so that 8 liter ha ${ }^{-1}$ humic acid increased peduncle length and there was no significant difference between control and 4 liter ha- ${ }^{-1}$ humic acid treatments (Table 4). Stem length positively responded to humic acid application, in other words, humic acid application increased stem length (Table 4). Although, no significant difference 
was observed between two levels of humic acid, plant height increased on account of humic acid application (Table 4). Spike number in $\mathrm{m}^{2}$ increased because of humic acid application (Table 4). According to the results, number of days until pollination increased when 8 liter ha ${ }^{-1}$ humic acid was applied (Table 4). Similar results were obtained in case of number of days until physiological maturity (Table 4).
Humic substances are organic materials that are common in terrestrial and aquatic environments. These substances refer to a category of naturally occurring organic materials result from the decomposition of plant and animal residues [26]. Organic acids make important contributions to soil stability and soil fertility leading to exceptional plant growth and micronutrient uptake. For example, humic acid have direct effect on biological

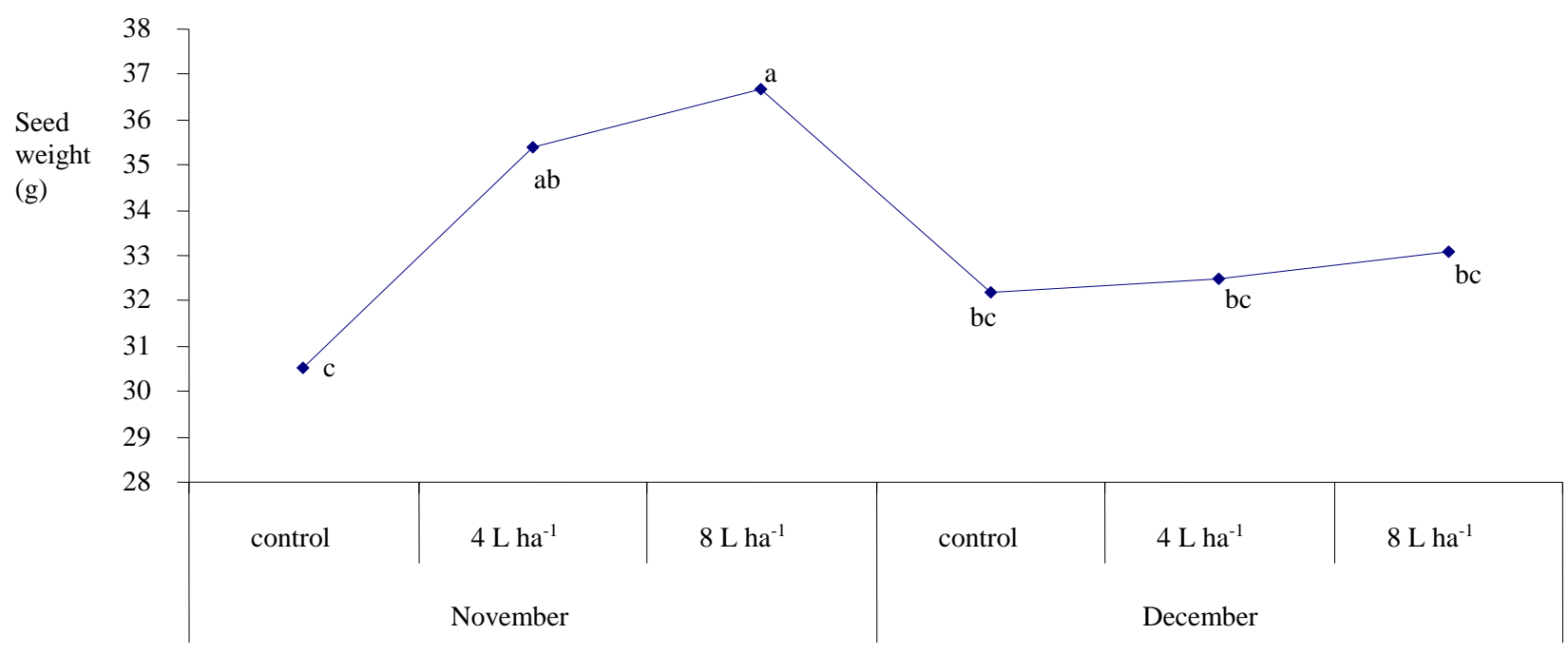

Interaction between sowing date and humic acid application

Figure 1: Interaction between seed sowing date and humic acid application on wheat seed weight. Values within the same column and followed by the same letter are not different at $\mathrm{P}<0.05$ by an ANOVA protected Duncan's Multiple Range Test

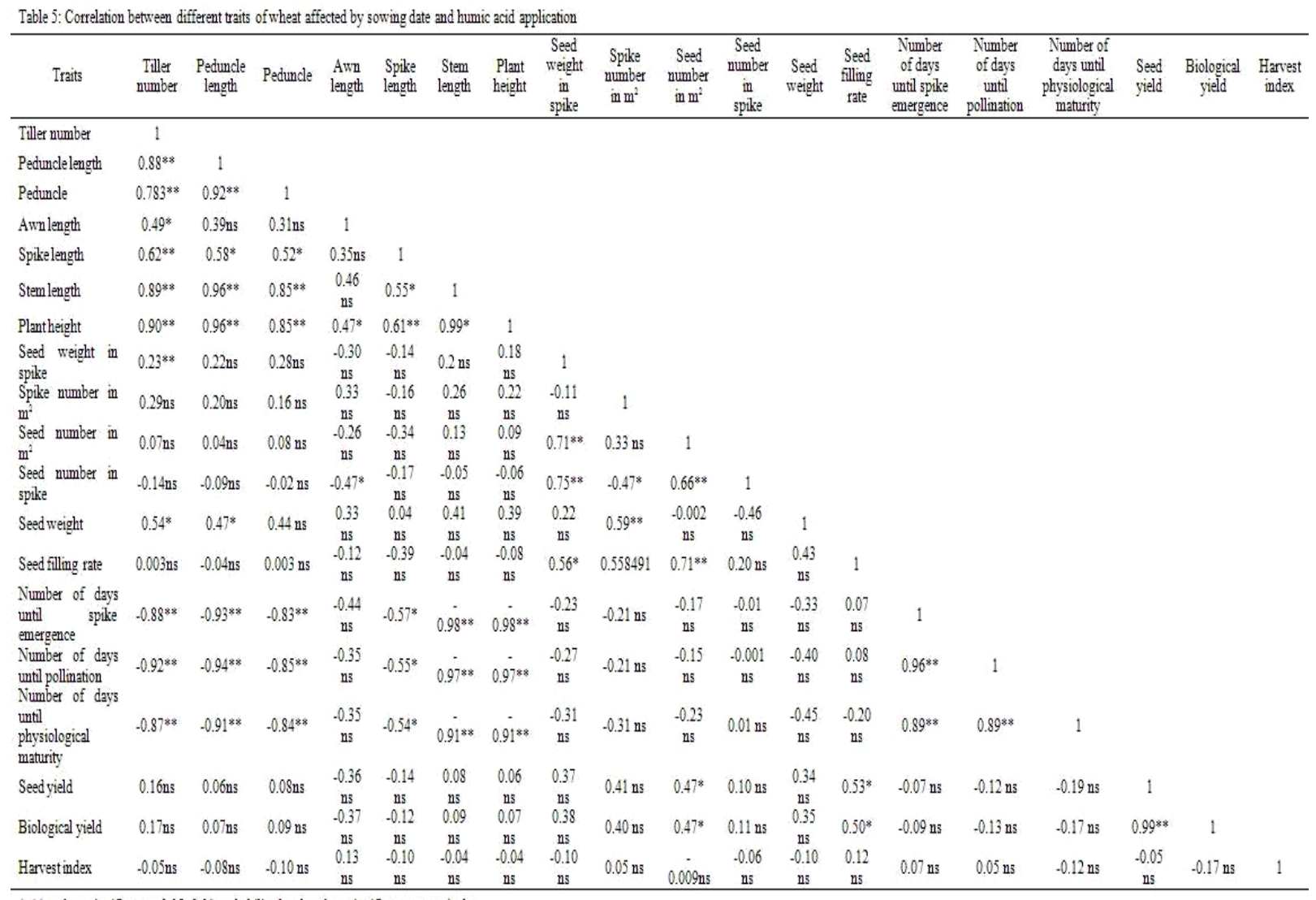

${ }^{8 * 8}$ and ns: significant at $0.05,0.01$ probability level and no significant, respectively 
membrane permeability and enzymatic activities or an indirect effect on plants by changing soil structure, increasing cationic exchange capacity, stimulating microbiological activity and capacity to solubilize or complex certain soil ions [27,28]. The effect on humic acid on plant growth has been reported by Fong et al. [29]. In addition, Yang et al. [30] have found that humic acid affect physiological process directly for example increases cell membrane permeability, nucleic acid biosynthesis, ion uptake and, enzyme activity. Increase in wheat seed yield has been reported by Shahryari et al. [31].

Interaction between seed sowing date and humic acid application is illustrated in figure 1. From the results, the highest seed weight was obtained when humic acid was applied on plants which have been sown in the middle of November. It should be note that there was no significant difference between 4 and 8 liter ha $^{-1}$ humic acid treatments (Figure 1). The lowest seed weight was recorded when wheat seed were sown in the middle of November and no humic acid was applied (Figure 1).

Humates are used as soil amendments could increase stress tolerance in wide range of crop plants $[12,13]$. The results of correlation analysis are demonstrated in table 5. There was positive and significant correlation between tiller number and some other traits such as peduncle length, awn length, spike length, stem length, plant height and seed weight. By contrast, correlation between tiller number and number of days until spike emergence, tiller number and number of days until pollination and tiller number and number of days until physiological maturity was negatively significant. Peduncle length positively correlated with spike length, stem length, plant height and seed weight, whereas the correlation between peduncle length and number of days until spike emergence, peduncle length and number of days until pollination and peduncle length and number of days until physiological maturity was negatively significant. Awn length positively correlated with plant height while the relationship between awn length and seed number in spike was negative. Spike length showed a positive correlation with stem length and plant height. Correlation between spike length and number of days until spike emergence, spike length and number of days until pollination and spike length and number of days until physiological maturity was negatively significant. Although, correlation between stem length and plant height was positively significant, the correlation with number of days until spike emergence, number of days until pollination and number of days until physiological maturity was significantly negative. Seed weight positively correlated with seed number and seed filling rate. The results indicated that there is positive correlation between spike number and seed weight and spike number and seed filling rate. Furthermore, positive correlation was observed between seed number in $\mathrm{m}^{2}$ and seed number in spike, seed filling rate, seed yield and biological yield. Correlation between seed filling rate and seed yield as well as between seed filling rate and biological yield was positively significant. Number of days until spike emergence positively correlated with number of days until pollination and number of days until physiological maturity. Similarly, number of days until pollination and number of days until physiological maturity positively correlated to each other. There was positive and significant correlation between seed yield and biological yield.

\section{CONCLUSION}

In general, late seed sowing decreases growing period length and vegetative growth which result to reduce seed yield. In addition, humic acid application increases tiller number, peduncle length, stem length, plant height, spike number in $\mathrm{m}^{2}$, number of days until pollination and number of days until physiological maturity. Finally, early seed sowing (in the middle of November) and application of 8 liter $\mathrm{ha}^{-1}$ humic acid is recommended to improve wheat seed yield.

\section{REFERENCES}

1. Shewry PR 2009: The health grain program opens new opportunities for improving wheat for nutrition and health. Nut. Bul. 34 225-231.

2. Murungu FS and T Madanzi 2010: Seed priming, genotype and sowing date effects on emergence, growth and yield in a tropical low altitude area of Zimbabwe. Afr. J. Agric. Res. 5(17) 2341-2349.

3. Aslani F and Mehrvar MR 2012: Responses of Wheat Genotypes as Affected by Different Sowing Dates. Asian J. Agri. Sci. 4(1) $72-74$

4. Munir AT, Rahman A and Tawaha M 2002: Impact of seeding rate, seeding date, rate and method of phosphorus application in faba bean (Vicia faba L.) in the absence of moisture stress. Biotechnol. Agron. Soc. Environ. 6 (3) 171-178.

5. Tanveer SK, Hussain I, Sohail M, Kissana NS and Abbas SG 2003: Effects of different planting methods on yield and yield components of wheat. Asian J. Plant Sci. 2 811-813.

6. Muhammad T, Asghar A, Muhammad AN, Akhtar H and Farhan K 2009: Effect of Different Sowing Dates on Growth and Yield of Wheat (Triticum aestivum L.) Varieties in District Jhang, Pakistan. Pak. j. life soc. sci. 7(1) 66-69.

7. Shafiq HM 2004: Modeling growth, radiation use efficiency and yield of wheat 
at different sowing dates and nitrogen levels under arid conditions of Bhawalpur. M.Sc. (Hons.) Thesis, Uni. Agri. Faisal.Pak.

8. Albayrak S and Camas N 2005: Effects of different levels and application times of humic acid on root and leaf yield and yield components of forage turnip (Brassica rapa L.). J. Agron. 4 (2) 130-133.

9. Fortun C, Fortun A and Almendros G 1989: The effect of organic materials and their humified fractions on the formation and stabilization of soil aggregates. The Science of the Total Environment 81 561-568.

10. Chen Y and Avaid T 1990: Effect of humic substances on plant growth. In: American Society of Agronomy and Soil Science Society of America (eds.), Humic substances in soil and crop science; selected Readings. American Soc. Agron. Madison, WI. P 161-186.

11. Russo RO and Berlyn GP 1990: The use of organic biostimulants to help low input sustainable agriculture. J. Sustainable Agriculture 1 19-42.

12. Gadimov A, Ahmaedova N, Alieva RC 2007: Symbiosis nodules bacteria Rhizobium legominosarum with peas (Pisum sativum) nitrate reductase, salinification and potassium humate. Azer. Nat. Acad. Sci. 25-31.

13. Shahriari R, Gurbanov E, Gadimov A, Hassanpanah D 2008: In vitro effect of potassium humate on terminal drought tolerant bread wheat. 14th Meeting of the International Humic Substances Society From molecular understanding to innovative applications of humic substances. Russia, 706-710.

14. Yang CM, Wang MH, Lu YF, Chang IF and Chou CH 2004: Humic substances affect the activity of chlorophyllase. $J$. Chem. Ecol. 30: 1057-1065.

15. Mollasadeghi V, Valizadeh M, Shahryari R and Imani A 2011: Evaluation of drought tolerance of bread wheat genotypes using stress tolerance indices at presence of potassium humate. American-Eurasian J. Agric. Environ. Sci. 10 151-156.

16. Haghighi S, Saki Nejad T and Lack S 2011: Effect of biological fertilizer of humic acid on metabolic process of biological nitrogen fixation. Life Sci. J. 8(3) 43-48.
17. SAS Institute Inc 2002: The SAS System for Windows, Release 9.0. Statistical Analysis Systems Institute, Cary, NC, USA.

18. Mahfoozi S, Limin AE and Fowler DB 2001: Influence of vernalization and photoperiod responses on cold hardiness in winter cereals. Crop Sci. 41 1006-1011.

19. Sharief AE and Keshta MM 2002: Influence of Sowing Dates and Plant Density on Growth and Yield of Canola (Brassica Napus, L.) under Salt Affected Soils in Egypt. Sci. J. King Faisal Uni. 3 65-78.

20. Chen C, Jackson G, Karnes N, Wichman D, Johnson G, Johnson D 2005: Determining the feasibility of early seeding canola in the northern Great Plains. Agron. J. 97 12521262.

21. Gaudat DA, Laroch A and Puckalski B 2001: Seeding date alters carbohydrate accumulation in winter wheat. Crop Sci. 41 728-738.

22. Destro D, Miglioranza E, Arias CAA, Vendrame $\mathrm{JM}$ and Vieira de Almeida C 2001: Main stem and tiller contribution to wheat cultivars yield under different irrigation regimes. Brazil. Arch. Biol. Technol. 44 325-330.

23. Mendham NJ, Shipway PA and Scott RK 1981: The effects of delayed sowing and weather on growth, development and yield of winter oil seed rape. J. Agric. Sci. Camb. 97 389- 415

24. Brooking IR and Jamieson PD 2002: Temperature and photoperiod response of vernalization in near isogenic lines of wheat. Field Crops Res. 79 21-38.

25. Thiry DE, Sears RG, Shroyer JP and Paulsen GM 2002: Keeping up with research: Planting date effect on tiller development and productivity of wheat. Agricultural Experiment Station and Cooperative Extension Service.

26. MacCarthy P 2001: The principles of humic substances. Soil Sci. 166 738-751.

27. Valdrighi MM, Pera A, Agnolucci M, Frassinetti S, Lunardi D, Vallini G 1996: Effects of compost-derived humic acids on vegetable biomass production and microbial growth within a plant (Cichorium intybus)soil system: a comparative study. Agri. Ecosys. Environ. 58 133-144. 
28. Biondi FA, Figholia A, Indiati R, Izza C 1994: Effects of fertilization with humic acids on soil and plant metabolism: a multidisciplinary approach. Note III: phosphorus dynamics and behaviour of some plant enzymatic activities. In: Senesi, N., Miano, T.M. (Eds.), Humic Substances in the Global Environment and Implications on Human Health. Elsevier, New York, pp. 239-244.

29. Fong SS, Seng L and Mat HB 2007: Reuse of nitric acid in the oxidative pre treatment step for preparation of humic acids from low rank coal of Mukah, Sarawak. J. Brazil. Chem. Soc. 18 (1) 41-46.
30. Yang CM, Wang MH, Lu YF, Chang IF and Chou CH 2004: Humic substances affect the activity of chlorophyllase. J. Chem. Ecol. 30(5) 1057-1065.

31. Shahryari R, Gadimov A, Gurbanov E and Valizade M 2009: Application of potassium humate in wheat for organic agriculture in Iran. Abstracts Book of Go Organic International Symposium. The Approach of Organic Agriculture: New Market, Food Security and a Clean Environment. Bangkok, Thailand. P 59. 